\title{
The Price of Women's Employment in Business Industry in Ethiopia: A Phenomenological study in Addis Ababa
}

\author{
Mulu Bzayene \\ Raya University, Maichew, Ethiopia
}

\begin{abstract}
In Ethiopia, thousands of women and girls are openly selling sexual services in bars, restaurants, hotels, and night clubs and on the streets of the cities and towns of Ethiopia. Their entry into prostitution was the result of unemployment, poverty, peer influence, false promises from bar, restaurant and hotel owners and other related socio-economic factors. Once women engage in prostitution, they would experience physical, sexual and psychological abuses i.e. beatings, rapes and insults. The aim of this paper is to investigate the price of women's employment in business industry. This phenomenological study looks at the working experience of those women employed in massage parlors. In-depth interviews were employed. This paper shows that commercialization of sex in massage parlor is new phenomenon in Ethiopia. It attracts thousands of women to commercialize sex. Prostitution is invisibly practice in massage parlors in Addis Ababa. This paper also shows that long working hours and night work without overtime payments; unfair commission; obligation to wear only bra and pant at the workplace; and sexual, physical and psychological abuses are among prices women paid for their employment in massage parlors. This article generally reveals women's employment in massage parlor opens the possibility of prostitution and facilitates trafficking of women for the purpose of prostitution.
\end{abstract}

Keywords: Commercialization of sex, Massage parlor, Trafficking of women, Prostitution, Violence, Women's rights

DOI: $10.7176 /$ RHSS/9-11-07

Publication date:June $30^{\text {th }} 2019$

\section{Introduction}

Commercialization of sex in Ethiopia emerged with urbanization. The construction of the Ethio-Djibouti railways led to the proliferation in the city of drinking houses mainly traditional drinks like tella (i.e. local beer prepared by white) and tej(i.e. local beer prepared by honey) where the owners and traders in these houses gave extra service i.e. prostitution. The practice was not a shaming one before and during this time. Large number of prostitutes was reported in Addis Ababa just before the Italian Invasion (Yohannes, 1998, p. 2).

The Italian invasion of the 1941 that came to Ethiopia played a major role in the expansion of prostitution in Ethiopia in as far as the invasion compelled Ethiopian men to join the resistance forces to fight for independence for at least a year. As a result, their wives and children opted to migrate to towns in search of employment for survival and engaged in selling local drinks (Cheryl, Henock, Beza, Hawkins, \& Moody, 2011, p. 12). These women and girls were ultimately pushed to engage into work meet their need for survival (Yohannes, 1998, pp. 2-3). Thus, the modern type of prostitution and/or exchange of money for sexual services i.e. the commercialization of prostitution are closely associated with urbanization, construction of Ethio-Djibouti railways and the Italian invasion.

In this global world, prostitution has become the most visible phenomenon in Ethiopia. There are large numbers of women openly selling sexual services both in indoor and on the street of main towns at nighttime. Family Health International (Cheryl, Henock, Beza, Hawkins, \& Moody, 2011, p. 12) in its report on the sex workers' population in Addis Ababa identified that 8134 sex workers are working in nightclubs, bars, restaurants and small residential home-brewed alcohol kiosks and 250 sex workers are on the street. Lalor (2000, p. 9) estimates that seven percent of the adult female population of Addis Ababa regularly engaged in multi partner sexual contacts, predominantly prostitute-client contacts.

Now, it has widely been saying that commercialization of sex has changed its form and practices under the guise of massage parlors in Addis Ababa (Cheryl, Henock, Beza, Hawkins, \& Moody, 2011, p. 19). There are massage parlors that run prostitution rather than massage services and health treatments in Addis Ababa. (Mekonnon, 2013). This piece seeks extensive investigation. This study however investigates the cost of women's employment in massage parlor industry.

This study is a study phenomenological approach that investigates the experience of women in the industry. In doing so, five women employed in massage parlor through snowball sampling are participated. I interviewed each woman separately. This was employed to understand whether their employment has negative or positive impact in their life, does it empower or violate them, or does it have exploitative or encouraging working condition? The study is thus limited in the scope to the analysis of the consequence of women's employment in massage parlor.

In order to do that, I will first, section one, discuss the literature review. I will dwell the historical 
development of massage parlor industry, massage parlor in th $21^{\text {st }}$ century and legal instruments relevant to women's rights. In second section, I will discuss research methodology of the study. In third section, findings and analysis of the study will be discussed and followed by conclusion.

\section{Literature}

\section{Massage Service: An overview}

The practice of massage is traced back to antiquity (Smith, Sullivan, \& Baxter, 2011; Beck, 2010). Massage is an integral part of culture and major part of medicine for thousands of years throughout the world (Beck, 2010, p. 11). For instance, in china, massage was practiced as early as 3000 B.C.; in Japan around the sixth century A.D; in India for more than 3,000 years (Beck, 2010, pp. 4-5) and the Traditional Thai Massage was practiced over 2500 A.D. (Karges, 2011, p. 2). Chinese Massage; Swedish massage; "Shiatsu" (a Japanese form of massage utilizing finger and palm pressure and stretching techniques); Thai traditional massage (a form of bodywork involving assisted stretching) (Ryan, Keiwkarnka, \& Khan, 2003 , p. 70); "Wegesha" (Ethiopian Traditional massage) (Wondwosen, 2005, p. 47) are some of the types of traditional massage practiced for many years (Kumar, Beaton, \& Hughes, 2013; Wieting, 2013).

In the sixteen, seventeen and eighteen centuries, medical practitioners employ massage as part of their healing treatments. At this time, massage was widely practiced for the protection of health and the treatment of disease (Beck, 2010, p. 11).

By the end of $18^{\text {th }}$ century, the practice and art of massage integrated into the medicine curriculum. At this time, massage was recognized as a fundamental treatment of physical therapy and the number of practitioners and schools of massage were increased (Beck, 2010, p. 12). In the early 1900, Germany and Scandinavia physicians incorporated massage in their teachings on the medical field and published various writings on techniques and benefits of massage therapy. Ultimately, they recommended to the people to use therapeutic exercises, massage and baths for the restoration and promotion of the healthy functioning of all body systems (Beck, 2010, p. 12).

In 1950s, massage used to treat injuries, to relaxation and athletic activities. For instance, in the Second World War, massage was used as a restorative treatment in the rehabilitation of injuries in a large scale in the hospitals of the Armed Forces. At that time, there were various reasons that precipitated massage to return to the place of prominence in the health care system in United States (Beck, 2010, pp. 14-15). First, the exclusion of teaching massage from medicine curriculum in the beginning of the $20^{\text {th }}$ century increased the interest and value of massage in the medical assistants and the public in general. The expensiveness of the usual medicine and increased awareness of physical and mental fitness influence the people to look for possible alternatives in health care, development of the wellness model and the importance of controlling stress are other reasons for the revival of the practice of massage (Beck, 2010, p. 14).

However, the scientific and medical use of massage and its status has been declined in the twentieth century. Abuses in the education and practices of massage were among the reasons for the decline. Many schools recruit trainees dishonestly and offered inadequate trainings. Ultimately, the graduates were incompetent and in debt to the school and required to work in clinics where unfortunate massage offered and on houses of prostitution. Moreover, these schools provided false certification and unreliable advertising. These seem exploitation and morally wrong practices (Beck, 2010, p. 13). As a result, various electrical devices such as vibrator were innovated instead of treating disease by diet, exercise and bathing; for the same reason physicians did not learn massage as part of their training and nurses were learn only the system of administering a back massage (Beck, 2010, p. 14).

The practice and art of massage persists until today. It becomes an integral part of medical treatment both in rural and urban areas of the world. It practices in hospitals, clinics, hotels, massage parlors, resorts, and sport clubs in a modernized manner for the purpose of relaxation, sport activities and rehabilitation (Beck, 2010, p. 14). In most instances, the traditional Chinese medical practice developed through many years massage experience on the body where various movements such as rubbing, pressing, or manipulations most effective. Now, it is an integral part of the Chinese health system and practiced in China's medical clinics and hospitals (Beck, 2010, p. 4).

Massage service is also not a new phenomenon in Ethiopia. But it has been operated in traditional ways and through traditional tools. Ethiopian societies have been used only traditional medicines to treat health problems until the modern (western) medicine came to Ethiopia with the arrival of missionary doctors, nurses and midwives in the last quarter of the $19^{\text {th }}$ century (Teferi \& Rao, 2013, p. 2). It is called as Wegesha in Amharic language. It is a traditional medicine used to rehabilitate injured persons using butter or oil and fire. It is still used to treat fractures (Sebberat, in Amharic) and Sprains (Walamta, in Amharic) together with the modern medicine probably because of their accessibility and their culturally recognized responses to illness in Addis Ababa (Wondwosen, 2005, p. 28).

Recently, hospitals, clinics, hotels, resorts are providing massage services in Addis Ababa (Getahun, 2014, 
p. 6). Swedish massage, Aroma massage, Morocco bath, hot stone and Stem services are among the service provided in these establishments (Mekonnon, 2013; Getahun, 2014, p. 6). Besides, massage parlors are legally established as formal business sectors.

\section{Massage Parlor Industry in the $21^{\text {st }}$ Century: Over view}

Massage parlor industry is legally established to provide massage and health related services. But sexual services are providing under the guise of these legalized service in all over the world. It becomes a newly emerging and lucrative establishment of prostitution in the world. It attracts millions of women from different small scale and related industries. About 40 million prostitutes are engaged in massage parlors (Kennedy, 2012, p. 3). It is also among the most lucrative industries in the world (Poulin, 2003, p. 41) that generates billion US dollars per year (Robinson, 1997, p. 243). In Birmingham, thousands of women are employed massage parlors and nearly 14,000 men each week are bought their services (Pateman, 1988, p. 190).

This is because women perceived that it is protective and lucrative industry. On the one hand, sexual services providing procedure in massage parlor is quite different from other industries where direct sexual services are provided. First, customers are required to pay massage service's fees before they meet women and sexual service. At the meantime, they could negotiate with masseuses for sexual services (Nemoto, Iwamoto, Eilkhani, Sakata, \& Le, 2009, p. 3). Customers perceive that having sex with masseuses in massage parlors is safe and secured as compared to others, on the other (Karim, Karim, \& Zondi, 1995, p. 1521).

In Norway, thousands females are employed in many different prostitution avenues but most of them are employed in massage parlors. Since the early 1990s, the image of media on massage parlor prostitutes was changed and hence the massage parlor industry becomes volatile in Norway than before (Skilbrei, 2001, p. 65). Massage parlor industry is advertized as new phenomenon of prostitution for clients and employees in a widely read Norwegian Newspapers" (Skilbrei, 2001, p. 66). This shows that massage parlor is a new form of prostitution in Norway.

In San Francisco, massage parlors traffic women to provide sexual service under the guise of massage service (Nemoto, Iwamoto, Eilkhani, Sakata, \& Le, 2009, p. 3). There, massage parlors' owners recruit Asian immigrant women for the purpose of prostitution (Nemoto, Operario, Takenaka, Iwamoto, \& Le, 2003, p. 246). Immigrant women from South Korea, China, Thailand and Vietnam are trafficked to provide sexual service in massage parlors due to lack of employment and limited language skills (Nemoto, Operario, Takenaka, Iwamoto, \& Le, 2003, p. 246; Nemoto, Iwamoto, Eilkhani, Sakata, \& Le, 2009, p. 3).

However, Women employed in all forms of sex industry including massage parlors experience sexual, physical and psychological violence (Veen, 2001, p. 40). It is about buying and selling of women's sexuality like commodities. These sex industries sustain patriarchal domination, which is incompatible with human dignity (Doezema, 2005, p. 76).

Farley ( 2005, p. 954 and 2004, p.1096), also argues that women in all forms of prostitution experience daily violence that is physical assaults, rapes and beatings, insults apart from being used as sexual object that the victim experiences sexual abuse. The transnational study entitled "Prostitution and Trafficking in Nine Countries $^{1}$ : An Update on Violence and Posttraumatic Stress Disorder" found that out of 854 prostitutes participated in the study, 625 of them had been experienced physical assaults, 475 of them reported they had been raped and 375 of them experienced sexual violence (Farley, et al., 2003, p. 35). They experienced helath problems such as tuberculosis, sexual transmitted diseases, sleeplessness, depression, cervical cancer, brain injury resulting from head trauma, anxiety disorders, infertility and early mortality" (Farley, et al., 2003, p. 53). Worsening the situation, they also suffer murder. For instance, in Canada out of four thousand women killed by serial murderers in 1982, one-third of them were women employed in sex industry (Leidholdt, 1992, p. 138).

In San Francisco, women working in massage parlors also experienced physical violence from customers, pimps and massage parlor owners/managers, and psychological and sexual abuses are lived experiences of women in massage parlors (Nemoto, Iwamoto, Eilkhani, Sakata \& Le, 2009, p. 19). The working situations of women employed in massage parlor are exploitative (Nemoto, Operario, Takenaka, Iwamoto, \& Le, 2003, p. 252).

So, although sex industry is one of the profitable industries in the world, women did not benefit from the income made from (CATW, 2005, p. 1). The beneficiaries are always their pimps, traffickers, madams, or husbands as well as to send back to the family members who sold her into.

\section{Massage Parlor in Ethiopia}

Massage parlor industry is a new business establishment where sexual service is given under the guise of massage services in Addis Ababa. In Ethiopia, sexual service has been given in tella and tej bet, hotel, bars, restaurants and on the streets. Its history is traced back to the $17^{\text {th }}$ century (Pankhurst, 1974, p. 159). At this, time,

${ }^{1}$ Canada, Colombia, Germany, Mexico, South Africa, Thailand, Turkey, United States and Zambia 
it was not regarded as an immoral and illegal act. The exchange of sexual services was operated at local drinking houses including tej bet and tella bet. Such relationship between women and their clients was maintained confidentially. This kind of relationship is described as a traditional form of prostitution (Yohannes, 1998, p. 2).

The commercialization of sex in Ethiopia emerged with urbanization. The construction of the EthioDjibouti railways led to the proliferation in the city of drinking houses mainly traditional drinks like tella and tej where the owners and traders in these houses gave extra service i.e. prostitution. The practice was not a shaming one before and during this time. Large number of prostitutes was reported in Addis Ababa just before the Italian Invasion (Yohannes, 1998, p. 2). The Italian invasion of the 1941 that came to Ethiopia played a major role in the expansion of prostitution in Ethiopia in as far as the invasion compelled Ethiopian men to join the resistance forces to fight for independence for at least a year. As a result, their wives and children opted to migrate to towns in search of employment for survival and engaged in selling local drinks (Cheryl, Henock, Beza, Hawkins, \& Moody, 2011, p. 12). These women and girls were ultimately pushed to engage into work meet their need for survival (Yohannes, 1998, pp. 2-3). Thus, the modern type of prostitution and/or exchange of money for sexual services i.e. the commercialization of prostitution is closely associated with urbanization, construction of EthioDjibouti railways and the Italian invasion.

Women employed in sex industry experienced sexual assaults, beatings, theft, unwanted pregnancies, illness and exposure to sexually transmitted disease. Mehret et al (cited in Lalor, 2000, p. 10) also signifies that women are assaulted in the industry because they refused to engage in "deviant practices" i.e. anal or oral sex. The same study revealed that from 2,663 randomly selected female prostitutes 1.7 and $0.2 \%$ of them were obliged to "anal sex" and "oral sex" respectively (Lalor, 2000, p. 11).

\section{Women's Employment in the Globalized World}

Globalization expands the job opportunities available to women and increases their independent earnings, and creates additional options in their households as well as in social life, and empowers women to participate in workplace in their homeland and abroad (Gray, Kittilson, \& Sandholtz, 2005, pp. 5-6). At the same time, the spread of modernization that threaten patriarchy and discrimination against women allows women a greater part in the social, political and economic lives of societies. So, it contributes to free of women from the hands of the patriarchy and authority of male-dominated global economy (Neumayer \& Soysa, 2011, p. 1066).

But women in Latin America, Asia and Sub-Saharan Africa including Ethiopia are still participated in informal economy. Informal economy refers to unregistered, unregulated, untaxed business and low profit sector, especially in developing countries like Ethiopia (Spring, 2009, p. 12; Pearson, 2007, p. 202).

As said above, the majority of Ethiopian women have also been participated in informal business sectors (Martha, 2012, p. 6). In response, Growth and Transformation Plan (GTP) is also a program that identified empowerment of women as one of the strategic pillars of the plan (FDRE, 2010, p. 8). In addition, Micro and Small Enterprises (MSEs) are among the industries and sub-sectors received special support in the strategic directions of Growth and Transformation Plan (FDRE, 2010, p. 27). GTP articulates that MESs plays significant role in the national development activities. MSEs are employment creation strategies especially for women (FDRE, 2010, p. 28). In light with this, GTP aims to "create employment opportunities for about 3 million people, provide training of trainers for 10, 000 professional, providing training for about 3 million operators in the areas of entrepreneurships, handcraft, technical and vocational and develop 15, 000 hectares of land, construct shade and buildings for operators organized in enterprises" (FDRE, 2010, p. 28).

The MSEs Development Strategy encourages women to participate in "growth-oriented sectors like car parking services, solid waste collection, beauty Salon" etc to reach the participation of women equal to men (Addis Ababa Bureau of Micro and Small Enterprises, 2013, p. 15). The Agency also provides Micro and Small Enterprises development services such as "credit facilities, working premises, market linkage, trainings and professional advices" (Addis Ababa Bureau of Micro and Small Enterprises, 2013, P. 17).

Addis Ababa, about 262, 355 (33\%) women are working in small and micro enterprises and 93, 348 women access more than 1 million loan service (Addis Ababa Bureau of Women, Children and Youth Affairs, 2013, p. 30). Moreover, development projects also necessarily developed by giving special attention to women's economic benefits. For instance, about 3190 women who were living by selling firewood in Yeka, Gulele and Kolfe Keraniyo sub-cities have supported to come together in different formal business sectors including Textile work, Cooking and vegetable that enable them to generate their income (Addis Ababa Bureau of Women, Children and Youth Affairs, 2013, pp. 31-32).

But still the women's employment status is not well addressed. At the meanwhile, the introduction and proliferation of massage parlors, day party, nightclubs, and chewing chat houses pulls women to engage into immoral and legally prohibited practices in Ethiopia (Sintayehu, et al., 2013, p. 23). Massage parlors are identified as contributing settings where the abovementioned immoral and illegal activities like sexual service are practiced (Sintayehu, et al., 2013, p. 104). 


\section{Legal Instruments Relevant to Women's Rights to work}

Although the concept dignity was relatively prominent in the political history, it was since the first half of the $20^{\text {th }}$ century to be central issue of the domestic and international laws. But since the 1948, the use of human dignity becomes central in human rights discourses (McCrudden, 2008, p. 667). Article 22 of UDHR provides "Everyone, as a member of society, has the right to social security and is entitled to realization [...] of the economic, social and cultural rights indispensable for his dignity and the free development of his personality". This shows that women in massage parlors have the right to equality and social security indispensable for their dignity. They have also the freedom of all forms of exploitation such as abuses at the workplace, trafficking and exploitation of the prostitution of women as incompatible with human dignity.

Article 23(3) of UDHR set in the context of right to work, also provides that "Everyone who works has the right to just and favorable remuneration ensuring for himself and his family an existence worthy of human dignity, and supplemented, if necessary, by other means of social protection". This shows that women in massage parlors have the right to choose the type of work that they want to get into and the state bears a duty to see to it that laws protect the working conditions of women in massage parlors.

Women working in massage parlors are entitled the right to "life, liberty, security, equality, freedom from discrimination and effective remedy for violations" (Article 6, 9, 14 of ICCPR). At the same time, Article 6, 7 \& 9 of ICESCR also provides women working at massage parlors the right to work; the right to enjoy just and favorable conditions of work; the right to social security including social insurance.

Convention on the Elimination of All Forms of Discrimination against Women (hereinafter, CEDAW) ${ }^{1}$ sets out the steps to eliminate discrimination against women that violates the principles of equality of rights and respect for dignity of human beings (Para. 7 of the preamble of CEDAW). CEDAW in this case obliges State Parties to take all measures to eliminate discrimination against women, and modify the social, cultural and practices patterns that basis on the idea of inequality and inferiority of women (Article $2 \& 5$ of CEDAW). In relation to this, the General Recommendation No.192 states that "Poverty and unemployment force many women, including young girls, into prostitution. Prostitutes are especially vulnerable to violence because their status, which may be unlawful, tends to marginalize them. They need equal protection of laws against rape and other forms of violence". In other words, prostitutes are vulnerable to all forms of exploitation and social and economic marginalization as much as all women face. Thus, women in massage parlors are entitled to the right to work under free, safe and fair working conditions just like any other class of employees.

International Labour Organization (ILO) adopts numerous Conventions and regulations relevant to women's rights in workplace. ILO Convention No. 1 in its Article 2 stipulates "eight hours per day and 48 hours per week" as normal working hours excluding over time hours. Regarding the women in massage parlors employed on shift, Article 2 of Convention No.1 allows, "working in excess of eight hours in any one day and forty-eight hours in any one week. Nevertheless, the average number of hours over a period of three weeks or less does not exceed eight per day and forty-eight per week". Article 8 (1) of Convention No. 1 requires massage parlors' employers to notify "the hours at which work begins and ends, and where work is carried on by shifts, the hours at which each shift begins and ends; these hours shall be so fixed that the duration of the work shall not exceed the limits prescribed by this Convention". Thus, Article 8 (2) of Convention No. 1 concludes that employing women outside the hours fixed in Accordance with Article 1 of this Convention is an offence against the law (ILO, 1919). Convention No. 30 was adopted to extend the international limits of hours to cover those employed in commercial, industrial and trade establishments (ILO, 1930). Having said this, though the maximum hours of work excludes women working at massage parlors (Article 1 of Convention No. 1), the Committee of Experts recommends that every worker in the workplace including women in massage parlors should be entitled to standards concerning maximum hours of work (ILO, 2011, p. 9). Thus, women working at massage parlors are protected from long working hours in work place.

Women working at massage parlors have the right to dignity, the right to freedom sexual and physical, the right to work, rest and leisure time and the right to reasonable limitation of working hours and enjoy just and favorable working conditions.

Ethiopia has ratified human rights conventions as part effort to protect women from all forms of exploitation including physical and sexual abuse and thereby promote women's participation in social, economic and political affairs. One of the major instruments address women's rights is the Constitution of the Federal Democratic Republic of Ethiopia (hereinafter, the Constitution of FDRE). ${ }^{3}$ It protects women from all forms of abuses (FDRE, 1995, Article 18(1)).

Article 42 (2) of the Constitution of FDRE also recognizes women have the right to "reasonable limitation

${ }^{1}$ Convention on the Elimination of All Forms of Discrimination against Women, adopted by the General Assembly on December 18 , 1979 and entered into force on September 10, 1981

${ }^{2}$ General Recommendation No. 19 (11 ${ }^{\text {th }}$ Session, 1992) made by the committee on the United Nations Convention on the Elimination of All Forms of Discrimination against Women

${ }^{3}$ The Constitution of the Federal Democratic Republic of Ethiopia Proclamation No. 1/1995, adopted August1995, Addis Ababa 
of working hours, to rest, to leisure, to periodic leaves with pay, to remuneration for public holidays as well as healthy and safe work environment".

Similarly, the revised Criminal Code of the FDRE suppresses the trafficking of women for the purpose of prostitution (FDRE, 2005, p. 256). Article 634 of the Criminal Code of the FDDE reads, "Whoever, for gain, makes a profession of or lives by procuring or on the prostitution or immorality of another, or maintains, as a landlord or keeper, a brothel, is punishable with simple imprisonment and fine". Article 635 (a and b) of the Criminal Code of the FDRE also reads as "Whoever, for gain, or to gratify the passions of another: traffics in women or minors, whether by seducing them, by enticing them, or by procuring them or otherwise inducing them to engage in prostitution, even with their consent. keeps such a person in a brothel to let him out to prostitution, is punishable with rigorous imprisonment not exceeding five years, and fine not exceeding ten thousand birr, subject to the application of more severe provisions, especially where there is concurrent illegal restraint". Therefore, the act of inducing, enticing or procuring and keeping woman in massage parlors for the purpose of prostitution even with their consent is punishable in Ethiopia.

National Policy on Ethiopian Women (NPEW) is among the national policies formulated to protect and promote women's rights in Ethiopia (TGE, 1993). It describes that women are engaged in informal sectors where their rights are violated in Ethiopia (TGE, 1993, p. 8). So, NPEW is pertained to protect and promote women in massage parlors from all forms of violations including the vulnerability to prostitution, which challenges them to participate in all affairs of the country (Addis Ababa bureau of Women, Children and Youth Affairs, 2013, p. 22).

\section{Research Method and Methodology}

Massage parlor industry and its owners did not welcome you if they know that you are researching on their institution. But the challenging one I faced during my preliminary study was that sensitivity of the issue at that time and the reluctance of women to share their experience.

Phenomenological approach was employed to investigate the cost of women's employment in massage parlor industry in Addis Ababa. The study has intensively understood women's working conditions from their own view point and meaning. Then I analyzed the world based on their living experience.

First of all I held fieldwork in two massage parlors. These are massage parlors around Haya-hulet and Bole Medhanialem district on 07 March 2017and 3 March 2017 consecutively. Then, five respondent women were selected through snowball sampling. First, I met the first informant through my friend on 28 March 2017. I approached her that the objective of the study is to investigate the consequences of your employment in the newly emerging industry. The willingness and interest of the participants were taken into consideration. She welcomed my request. The first informant also approached the second and third informants. The fourth informant approached by the third one. The fourth informant also approached the fifth informant on 16 April 2017. Each interview took about an hour. Thus, in-depth interviews take place between 28 March and April 16 2017. I interviewed each informant in a private room located in nearby to their working places, namely Future Park, Kidist and Tsige bars and restaurants in Addis Ababa and at the time of when they were free.

\section{Findings and Analysis \\ Description of the study}

The objective of this paper is to investigate the invisible experience of women in massage parlor in Addis Ababa from their own experience. Addis Ababa is the capital city of Ethiopia. It is Ethiopia's largest metropolis where about 3 million people are living (Addis Ababa Bureau of Women, Children and Youth Affairs, 2013, p. 1). It comprises 10 sub-cities, namely Arada, Addis Ketema, Akaki kality, Bole, Gullele, Kirkos, Kolfe Keranio, Lideta, Nifas Silk Lafto and Yeka, and 99 kebeles (Gebre, Ayalew, Rahel, \& Workineh, 2009, p. 12).

Recently, hospitals, clinics, hotels, resorts and massage houses are provide massage services for the purpose of relaxation and sport activities, and rehabilitation of injuries in Addis Ababa. These all sectors provide massage service as supplementary ones. It is only massage parlor industry specifically regulated to provide massage services.

Massage parlors are newly emerging industry that placed at modern villas and buildings in the city. They are licensed to provide massage service by the Ethiopian Food, Medicine and Health Care Administration and Control Authority under the FDRE Ministry of Trade. ${ }^{1}$ The industry is expanding in the city corresponding with the development of people's understanding as the benefit of massage is more than rehabilitating injury. Of course, the prevalence of massage parlors in Addis Ababa indefinite even if significant number of massage parlors are geographically distributing in all strategic parts of the city where they can access customers.

Aroma and Swedish massage, Morocco bath, Soap bath, Stem and Hot Stone services are the services provided in the industry. Morocco bath costs 300 ETB; Aroma massage costs 200 ETB, Swedish massage costs 150 ETB, and hot stone, Stem and Soap bath cost 100 ETB including the Value Added Tax (VAT). Among these

${ }^{1}$ Council of Ministers Regulation No. 189/2010, Ethiopian Food, Medicine and Health Care Administration and Control Authority, 2010 
services, massage parlors also arrange Aroma massage service at the customers' homes, which costs 500 ETB. Masseuses and masseurs would have commission of 50 ETB, 30 ETB and 100 ETB if they provide Morocco bath, Swedish and Aroma massage and Aroma massage at the customers' homes respectively.

The owners of the industry are women. The customers of massage parlors are economically good part of the society. Foreigners, middle and higher-income Ethiopian such as Diasporas, businesspersons, athletes, and football players are the common customers of the industry. They are open for 24 hours.

In Addis Ababa, there are two massage training centers, namely Aroma and Welgeta Massage Training Centers. Aroma Massage Training Center trained more than 4000 massage professionals until 2017 and 70 percent of the trainees are females. The training courses are given in three and six months that costs 350 ETB per month.

After successful completion the training, massage professionals will be certified if they pass the exam of COC. Then the will be employed in massage parlors, hospitals, hotels, resorts, clinics etc. However, this study shows that those women participated in this study have no professional certificate. Their employment is facilitated by brokers.

\section{The Price of Women's Employment in Massage parlor}

The study reveals that the working time and working hours in massage parlors are unreasonable. The working time is arranged from 2:00 a.m. up to 12:00 p.m. as daytime shift and from 12:00 p.m. up to 4:00 a.m. nighttime shift. This is contradictory with Article 2 of ILO Convention No. 1 limits the working hours of women employed in any public and private organization to eight hours per day and forty-eight hours per week. Article 61 (1) of Ethiopian Labour Proclamation No. 377/2003 also stipulates that eight hours per day and forty-eight hours per week are normal working hours excluding the overtime hours. This shows that women in massage parlors are working longer than eight hours per day and forty-eight per week. Indeed, they are required to work for eleven hours per day and seventy-seven hours per week, which exceeds three hours a day and eighteen hours a week from the normal working hours that stipulated by ILO Conventions and Ethiopian Labour Proclamation.

In Addition, there is not overtime payment for the extra working hours in massage parlor industry. All working times are scheduled as normal working time. This also violates women's rights to overtime payment under Article 68 (b) of Labour Proclamation No. 377/2003 of Ethiopia. The proclamation says that any worker who works nighttime between ten o'clock in the evening and six o'clock in the morning shall be entitled at least the payment at rate of $1 \frac{1}{2}$ multiplied by the ordinary hourly rate.

So, employing women for long hours is violation of women's rights. It violates Article 24 of UDHR that recognizes women in massage parlor the right to "rest and leisure that encompasses a reasonable limitation of working hours". Article 7(d) ICESCR also includes working hours limits as elements of the right to "enjoy just and favorable working conditions". Article 15 of African Charter recognizes women in massage parlors "the right to work under equitable and satisfactory conditions and to receive equal pay for equal work". Article 13 (d) of African Women's Protocol protects women from "exploitation by their employers violating and exploiting their fundamental rights as recognized and guaranteed by conventions, laws and regulations in force". This is also a violation of women's rights to "reasonable limitation of working hours, rest and leisure time" (FDRE, 1995, Article 42 (2)).

The study also shows that those women in the industry are obliged to dress only bra and pant at the working time. This is deliberately arranged to cater more customers and excite customers' sexual interest. Customers are also ruled out to wear pant at the time of massage operation.

Therefore, keeping and arranging women for the purpose of sexual service in massage parlor is incompatible with human dignity. It contradicts with Article 2 (1) of the 1949 Convention prohibits keeping a woman for the purpose of prostitution in massage parlors and benefit from the prostitution of women as exploitation of the prostitution of women. At the same time, it is illegal as per Article 635 (b) of Criminal Code of FDRE that prohibits keeping and arranging a woman for the purpose of prostitution in massage parlors as an exploitation of the immorality of women. Article 12 (3) of labour Proclamation No. 377/2003 obliges massage parlors' employers to "respect workers human dignity". Thus, keeping women to provide sexual services and using women's sexuality to attract more customers is prohibited as it is a form of trafficking of women for the purpose of exploitation i.e. prostitution (Article 3 (a) of the Palermo Protocol).

The employed women in massage parlors have no salary. They paid as per service they provide that is commission. The amount of commission depends on the nature of the service. Massage services are given both inside and outside the parlor. The types of services given in massage parlor are Aroma and Swedish massage, Morocco bath, hot stone, stem and soap bath. The maximum commission is 100 ETB for Aroma massage given at customers' home. They usually get paid from 30 up to 50 ETB for in service.

The commission paid for the above service is unreasonable as compared to the tired nature of the work. Each services takes at least one hour and they are paid 30 ETB. This among cannot even afford lunch. The women insisted to the extent that they are working without payment. 
Because of this, they are only waiting for providing sexual service for customers. They will generate additional income for sexual services i.e. 'hand relief' and 'regular sexual intercourse' negotiable. They get paid 150 ETB for "hand relief" and 300 ETB for "normal sexual intercourse". As far as the commission they earn cannot afford their basic needs in employment, they forced to engage in sexual service in massage parlors (Nemoto, Operario, Takenaka, Iwamoto, \& Le, 2003, p. 252).

Sexual service is invisible practice in massage parlors. Unlike others, sexual service is secretly practice in massage parlors in Addis Ababa. Although this is illegal in Ethiopia, it is better source of income for those women working in massage parlors. The Ethiopian Commercial Registration and Business Licensing Proclamation No. 686/2010 in its Article 34 (1) states that "Any person who has been issued a business license to carry out any commercial activity so long as such activity is within the scope of the field of activity for which the license is issued, abide by the prohibitions and restrictions imposed by the provisions of sub article of this Article and other laws...".

Thus, providing sexual service under the guise of massage parlors is illegal because it is beyond the legitimated scope of massage parlor industry. Article 634 of Criminal Code of FDRE prohibits keeping women for the purpose of prostitution in massage parlors i.e. exploitation of the immorality of women.

The study also shows that women' employment in massage parlor industry is violent. On the one hand, women in massage parlor are responsible to provide sexual services up to customers' homes. It exposes them to physical, psychological and sexual abuses i.e. physical assault, denial of payment, refusal to use condom and rape when they get out from the parlors (i.e. out service), on the other hand. They could get out of the parlor in give massage service or sexual service with their customers. They are beaten and insulted when they are in duty of outside service. Out service is the dangerous part massage parlor industry in which they often experience sexual and physical abuses for the refusal having sex without condom.

Apart from being sexual objects of their customers, women in the industry experience sexual, physical and psychological abuses. International human rights instruments respond that pimping, inducing, enticing, financing, and keeping women for the purpose of prostitution in massage parlors is trafficking, which is incompatible with human dignity. Sexual, physical and psychological abuses are also violence against women.

Similarly, Ethiopia has ratified international human rights instruments such as the 1949 Convention and CEDAW that prohibit the trafficking of women for the purpose of prostitution and violence against women as part of its domestic law. National Policy on Ethiopian Women (NPEW) defines prostitution as "an occupation disliked upon by all societies, degrading to women, a manifestation of backwardness and a breeding ground for many kinds of diseases and social evils" (TGE, 1993, p. 9). The National Youth Policy also describes that large numbers of youth have been exposed to various social evils such as prostitution and street life (MYSC, 2004, p. 2), as aimed to protect young females from social evils including prostitution and support to rehabilitate the already victimized females in prostitution among its major issues.

The Constitution of FDRE prohibits the trafficking of women for the purpose of prostitution in massage parlors as against to women's rights. Article 634 of the revised Criminal Code of the FDRE also stated that the act of procuring and keeping a woman in massage parlors for the purpose of prostitution is crime as exploitation of the morality of women.

In massage parlor, women are obliged to wear "bra and pant" in the working time and to make sexual intercourse with customers to attract more customers by gratifying customers sexual passion. Therefore, women's sexuality is exploited in massage parlors for commercial purpose. This shows that women are treated as sexual objects in massage parlors, which is a violation of women's rights to freedom from all forms of exploitation including sexual exploitation in massage parlors.

Apart from being sexual objects, they experienced long working hours. First, they are required to work for eleven hours per day and seventy-seven hours per week, which exceeds three hours per day and twenty-nine hours per week from the normal working hours. Second, all times are normal working times of women in massage parlors without overtime payment. This means that the time after 10:00 o'clock in the evening up to 4:00 a.m. in the morning, which is an overtime work, is arranged as normal working hours in massage parlors. Hence, women in massage parlors are responsible to work the whole days of a week in addition to eleven working hours per day. This is also a violation of women's rights to rest and leisure time, to reasonable limitation of working hours and enjoy just and favorable working conditions. Furthermore, they are required to provide 'out service' i.e. Aroma massage arranged at customers' homes. At this time, they experienced physical, sexual and psychological abuses i.e. physical assault, denial of payment, refusal to use condom, insult and rape, which is violence against women.

\section{Conclusion}

Massage parlor industry is one of the lucrative business sectors of women in Addis Ababa. They are introduced to provide massage and other health related services in a separate institution. Thousands of women are attracted to the industry. 
There, prostitution is practice under the guise of massage service. Women are trafficked into massage parlors for the purpose of prostitution because the employed women have not competency of profession. Their entry is facilitated by brokers.

Women in massage parlor are employed for salary. Rather they are paid based on the amount of service they provide. They have no common source of income. Because of this, they forced to engage to sell sexual service inside and outside the industry.

The working procedure of the industry is abusive. They deliberately obliged to wear only bra and pant at the work time. This dressing procedure is arranged to cater customers and buy sexual service. Massage parlor owners have commission from women's income of each sexual service they provide. Customers are also ruled out to wear pant. So, you can imagine the exploitative condition of the industry.

Another abusive character of massage parlor is long working hour and time. This is prohibited as exploitation of workers in both public and private sectors. But women in the industry are responsible to work at least 11 hours per day and seven days per week. Overtime payment is unthinkable in the industry.

In addition to these, women in massage parlor are also experience violence. As mentioned above women in the industry have regular salary and unreasonable commission. Because of this, they forced to engage in prostitution and sell sexual service to satisfy their basic needs. At this time, they experienced sexual, physical and psychological violence by their customers frequently outside of the industry. This shows that regardless of the nature of the industry and if it practices prostitution violence against women is inevitable. Prostitution has a violent nature.

In general conclusion, women's employment in massage parlor where prostitution is practice under the guise of massage service led to long working hours, sexual, physical and psychological problems. Women's employment in massage parlor also opens the possibility of prostitution and facilitates trafficking of women for the purpose of prostitution.

\section{Bibliography}

Beck, M. F. (2010). Theory and Practice of Therapeutic Massage. USA: Erin O'Connor.

CATW. (2005). The Economics of Sexual Slavery. New York: CATW.

Cheryl, O., Henock, A., Beza, A., Hawkins, K., \& Moody, N. (2011). Sex work in Ethiopia: Mapping the impact of Law, Policy and Enforcement Practices. Paulo Longo Research Initiative , 1-38.

Farley, M., Cotton, A., Lynne, J., Zumbeck, S., Spiwak, F., Reyes, M. E., et al. (2003). Prostitution and Trafficking in Nine Countries: An Update on Violence and Posttraumatic Stress Disorder. Trafficking and Truamatic Stress, 33-74.

Gebre, Y., Ayalew, G., Rahel, S., \& Workineh, H. (2009). Resilience in Children Exposed to Sexual Abuse and Sexual Exploitation in Merkato, Addis Ababa, Ethiopia. Addi Ababa: The Oak Foundation.

Getahun, W. (2014, March 25). Sex work is spreading out under the guise of Massage Parlors. (A. Newspaper, Interviewer)

ILO. (2011). Working time in the twenty-first century: Discussion report for the Tripartite Meeting of Experts on Working-time Arrangements. Geneva: ILO publications .

Karges, C. (2011). Exploring the "Lazy Yoga" inThai Massage,. 1-31.

Karim, Q. A., Karim, S. S., \& Zondi, K. S. (1995). Reducing the Risk of HIV Infection among South African Sex Workers: Socio-economic and Gender Barriers. American Journal of Public Health , 1521- 1525.

Kennedy, R. (2012). Can prostitution as sex work ever be compatible with human rights? A feminist human and labour rights analysis of Thailand's sex industry. Lund University: School of Law , 1-84.

Kumar, S., Beaton, K., \& Hughes, T. (2013). The effectiveness of massage therapy for the treatment of nonspecific low back pain: a systematic review of systematic reviews. International Journal of Medicine , 733-741.

Lalor, K. (2000). The Victimization of Juvenile Prostitutes in Ethiopia. Dublin Institute of Technology , 1-25.

Leidholdt, D. (1992). Prostitution: A Violation of Women's Human Rights. Cardozo Women's law journal , $133-147$.

Martha, K. (2012). Employment Challenges in Ethiopia. Addis Ababa Univeristy , 1-30.

McCrudden, C. (2008). Human Dignity and Judicial Interpretation of Human Rights. The European Journal of International Law , 656-724.

Alazar, M. (Director). (2013). The Secrets and Story of Massage Houses in Ethiopia [Motion Picture].

Neumayer, E., \& Soysa, I. D. (2011). Globalization and the Empowerment of Women: An Analysis of Spatial Dependence via Trade and Foreign Direct Investment. Journal of World Development , 1065-1075.

Pankhurst, R. (1974). History of Prostitution in Ethiopia. Journal of Ethiopian Studies. , 159-167.

Pateman, C. (1988). The Sexual Contract. California : Stanford University Press.

Poulin, R. (2003). Globalization and the Trafficking and the Commodification. Canadian Woman Studies , 38-47. Ryan, C., Keiwkarnka, B., \& Khan, M. I. ( 2003 ). Traditional thai massage: unveiling the misconceptions and 
revealing the health benefits. Journal of Public Health and Development, 69-75.

Sintayehu, D., Tewabech, T., Aschenaki, D., Adanech, K., Liya, H., Haile, D., et al. (2013). The Negative Impact of Non-Ethiopian Cultures and traditional practices to Addis Ababa Society; A case of Youth and women. Addis Ababa: Addis Ababa Bureau of Women, Children and Youth Affairs.

Skilbrei, M.-L. (2001). The Rise and fall of the Norwegian Massage Parlors: Changes in the Norwegian Prostitution Setting in the 1990s . Feminist Review Collective , 63-77.

Smith, J. M., Sullivan, S. J., \& Baxter, G. D. (2011). A Descriptive Study of the Practice Patterns of Massage New Zealand Massage Therapists. International Journal of Therapeutic Massage and Body Work, 18-27.

Teferi, D., \& Rao, M. S. (2013). Demand for Traditional Health Care Services in Rural Ethiopia. Middle-East Journal of Scientific Research , 01-10.

TGE. (1993). National Policy on Ethiopian Women (NPEW) published on September 1993, Addis Ababa. Addis Ababa: Transitional Government of Ethiopia, the Prime Minister's Office of the Women's Affairs Office.

Veen, M. v. (2001). Rethinking Commodification and Prostitution: An Effort at Peacemaking in the Battles over prostitution. A Journal of Economics, Culutre and Society, 13 (2), 30-51.

Wieting, J. M. (2013, October 30). Massage, Traction, and Manipulation. Retrieved from Medscape: http://emedicine.medscape.com/article/324694-overview.

Wondwosen, T. (2005). Impacts of Urbanisation on the Traditional Medicine of Ethiopia. Journal of Anthropologist , 43-52.

Yohannes, Z. (1998, June). Clients of child prostitutes; A case in some selected areas of Addis Ababa. 1-96. Addis Ababa. 